\title{
Current Practice of Quality Assurance Scheme (QAS) in Different Medical Colleges of Bangladesh
}

\author{
Brig. General (Dr. ) Brayan Bankim Halder', Prof. Dr. Md. Ismail Khan ${ }^{2}$
}

\begin{abstract}
This descriptive cross sectional study was carried out to assess the current status of practice of Quality Assurance Scheme(QAS) in different government and non-government medical colleges of Bangladesh. Principals/academic coordinators and students of all the medical colleges were the study population. Sample size were 13 principals/academic coordinators and $760 \mathrm{MBBS}$ students of different phases. Convenience sampling technique was adopted to conduct the study. Two semi-structured self administered questionnaires one for the students and other for the principal/academic coordinator and one checklist were used to collect data from the respondents. Study revealed that $80.8 \%$ medical colleges have complete institutional framework of QAS and $68.1 \%$ medical colleges have fully functioning operational framework of QAS. Majority of the medical colleges (53.8\%) do not have student representatives in academic coordination committee and only $23 \%$ medical colleges collected the phase wise evaluation of the course by the students. More than sixty one percent (61.54\%) medical colleges have faculty development and review committee and $76.92 \%$ medical colleges have faculty development programme. Provision of exchange review visit by the academic coordinators is absent in $84.61 \%$ medical colleges. Almost all the medical colleges $(92.31 \%)$ prepared and submitted the QAS report to NQAB in the last year. Regarding teaching learning $56.7 \%$ students were satisfied/very satisfied. A significant number of students $(37.9 \%)$ gave negative opinion regarding recognition of students opinion in teaching learning. In the present study it was found that $9.1 \%$ teachers of the selected medical colleges were engaged in research work in last year, $15.5 \%$ teachers had publication and $14.8 \%$ teachers presented scientific paper at various level in last year.
\end{abstract}

\section{Introduction}

Quality is one of the most important issues facing the medical institute nationally and internationally today (WFME Global standard for quality improvement 2012). Defining "quality" is difficult as it is subjective and dynamic. It has different meaning for different stakeholders (Joshi 2012, p. 285 ). Grifin (2003) defines quality as ' the totality of features and characteristics of a product or service that bears on its ability to satisfy stated or implied need'. Quality in medical education can be defined in relative terms as a state of reaching required standards as prescribed by the external agencies and it meets those standards time and again (Sallis E 2002). In education, quality can be considered at both the production side i.e. creation of the next generation of appropriate medical graduates, and the perceptual side, which is the maintenance of the values and principles of the medical educational institutions. (Gale \& Grant 2011).

Quality Assurance is a set of procedures and activities intended to ensure that a product or service under development meets specified requirements (Biggs 2001, p. 221 ). It has also been defined as the product that is not only as per specifications but also fit for the purpose (Gale \& Grant 2011). Quality assurance can be managed through an institutional monitoring that should include the course evaluation, peer evaluation and the assessment.

${ }^{1}$ Director, Sir Salimullah Medical College \& Mitford Hospital, Dhaka.
${ }^{2}$ Head, Pharmacology \& Principal, Dhaka Medical College

Address of correspondence: Brig. Gen. (Dr.) Brayan Bankim Halder Director, Sir Salimullah Medical College Hospital, Dhaka.

E-mail: halderbrayan@gmail.com
The improved health of all peoples is the main goal of medical education (WFME Global standard for quality improvement 2012). This is also the overall mission of the WFME. In accordance with this mandate, WFME in a position paper (1998) launched the programme on International Standards in Medical Education. The purpose was to provide a mechanism for quality improvement in medical education, in a global context, to be applied by institutions responsible for medical education, and in programmes throughout the continuum of medical education (WFME, Global Standards for Qualit Improvement 2012 p.6).

The World Health Organization (WHO) has been actively advocating the reform and improved medical education to meet the changing needs of the current and future society, need for continuing medical education and interprofessional collaboration at both global and regional levels (WHO. Changing Medical Education 1991). For the past three to four decades WHO has intensified its efforts and has collaborated with a number of organizations and institutions to carry out activities aimed at improving human resources for health through better quality education ((WHO/WFME Guidelines 2005).

In Bangladesh, standards of the medical education and practices of all the undergraduate institutes are supervised and regulated by the Bangladesh Medical and Dental council (BM\&DC). Centre for Medical Education (CME) is acting as secretariat of QAS in collaboration with Director of Medical Education of Director General of Health Services (DGHS) ,Bangladesh Medical and Dental Council (BM\&DC), Ministry of Health and Family Welfare(MOHFW),

Bangladesh Journal of Medical Education 2015;6(1):2-7. C 2015 Halder et el., publisher and licensee Association for Medical Education. This is an Open Access article which permits unrestricted non-commercial use, provided the original work is properly cited. 
Universities, World Health Organization ( WHO) and Association for Medical Education(AME), Bangladesh are working together to develop and maintain quality medical education in the country (Talukder 2010).

\section{Materials and Methods}

This descriptive type of cross sectional study was undertaken to assess the current status of practice of Quality Assurance Scheme(QAS) in different government and nongovernment medical colleges of Bangladesh. Medical college authorities (Principals / Academic coordinators ) and students of medical colleges of different phases were the study population. Convenience sampling method was used to collect information from 13 Principals / academic coordinators and 760 students of different phases of selected medical colleges by using a self administered semi structured questionnaire for the medical college authority, a self administered semi structured questionnaire with five points Likert scale for the students and a checklist to review the annual report on quality assurance scheme (QAS). Quality was controlled by pretesting the questionnaire out side the study area. After necessary feedback the questionnaire was modified and made it final .

After collection of data a further quality- control check was done for completeness and internal consistency of the data. Then the data were entered in the computer, processed and analyzed using computer SPSS programme. Necessary permission were taken from all the concerned authorities to conduct the study. The students were thoroughly briefed about the purpose of the study and only the volunteer respondents were included in the study .

\section{Results}

Table 1. Distribution of the medical colleges by the opinion of the authorities about the institutional framework of the QASconclusion $(53,83 \%)$ and recommendation $(55,86 \%)$. None of the sections in any document out of 64 could be graded as exemplary (Fig 1).

Table 1 shows that $100 \%$ medical colleges have all the committees of the QAS like, academic council, academic coordination committee, phase coordination group and subject coordinators . Forty six percent medical colleges have student representatives in academic co-ordination committee and $53.85 \%$ colleges do not have student representatives in academic co-ordination committee. Again $38.46 \%$ medical colleges have student representatives in phase co-ordination group and $61.54 \%$ medical colleges do not have student representatives in phase co-ordination group .

\begin{tabular}{|l|c|c|c|}
\hline $\begin{array}{l}\text { Different committees of } \\
\text { the QAS }\end{array}$ & \multicolumn{3}{|c|}{$\begin{array}{l}\text { Opinion of the authorities } \\
\text { about the institutional } \\
\text { framework of the QAS }\end{array}$} \\
\hline & $\begin{array}{c}\text { Yes } \\
\text { n (\%) }\end{array}$ & $\begin{array}{c}\text { No } \\
\text { n (\%) }\end{array}$ & $\begin{array}{c}\text { Total } \\
\text { n (\%) }\end{array}$ \\
\hline Academic Council & $13(100$ & - & $13(100)$ \\
\hline $\begin{array}{l}\text { Academic co- ordination } \\
\text { committee }\end{array}$ & $13(100$ & - & $13(100)$ \\
\hline Phase co-ordination group & $13(100$ & - & $13(100)$ \\
\hline Subject coordinators & $13(100$ & - & $13(100)$ \\
\hline $\begin{array}{l}\text { Student representatives in } \\
\text { the academic co-ordination } \\
\text { committee }\end{array}$ & $6(46.1)$ & $7(53.8)$ & $13(100)$ \\
\hline $\begin{array}{l}\text { Student representatives in the } \\
\text { phase co-ordination group }\end{array}$ & $5(38.5)$ & $8(61.5)$ & $13(100)$ \\
\hline
\end{tabular}

Table 2. Distribution of the medical colleges by the opinion of the authorities about the operational framework of the QAS

\begin{tabular}{|c|c|c|c|c|c|c|c|}
\hline \multirow[t]{2}{*}{$\begin{array}{l}\text { Issues / events related to operational } \\
\text { framework of the QAS }\end{array}$} & \multicolumn{7}{|c|}{$\begin{array}{l}\text { Different levels of opinion of the authorities about the operational } \\
\text { framework of the QAS }\end{array}$} \\
\hline & $\begin{array}{l}\text { Always } \\
\text { n (\%) } \\
\quad 5\end{array}$ & $\begin{array}{c}\text { Most of } \\
\text { the time } \\
\text { n }(\%) \\
4\end{array}$ & \begin{tabular}{|c|} 
Sometimes \\
n (\%) \\
$\mathbf{3}$
\end{tabular} & $\begin{array}{l}\text { Rarely } \\
\text { n (\%) } \\
\quad 2\end{array}$ & $\begin{array}{l}\text { Never } \\
\text { n (\%) } \\
\quad 1\end{array}$ & $\begin{array}{l}\text { Total } \\
\text { n }(\%)\end{array}$ & $\begin{array}{l}\text { Mean } \\
\pm \text { SD }\end{array}$ \\
\hline $\begin{array}{l}\text { Presence of students representatives in the } \\
\text { academic coordination meeting? }\end{array}$ & $3(23.1)$ & - & $2(15.4)$ & $1(7.7)$ & $7(53.9)$ & $13(100)$ & $\begin{array}{l}2.31 \\
1.81\end{array}$ \\
\hline $\begin{array}{l}\text { Collection and analysis of the phase wise } \\
\text { evaluation of the course by the students }\end{array}$ & $3(23.1)$ & $3(23.1)$ & $4(30.8)$ & $1(7.7)$ & $2(15.4)$ & $13(100)$ & $\begin{array}{l}3.31 \\
1.448\end{array}$ \\
\hline $\begin{array}{l}\text { Filling up of personal review form by the } \\
\text { faculty members }\end{array}$ & $1(7.7)$ & - & $1(7.7)$ & $1(7.7)$ & $10(76.9)$ & $13(100)$ & $\begin{array}{c}1.54 \\
1.122\end{array}$ \\
\hline $\begin{array}{l}\text { Evaluation of the personal review form by } \\
\text { the faculty development and review } \\
\text { committee }\end{array}$ & - & - & $2(15.4)$ & $1(7.7)$ & $10(76.9)$ & $13(100)$ & $\begin{array}{l}1.38 \\
1.01\end{array}$ \\
\hline $\begin{array}{l}\text { Collection of reports of external } \\
\text { examiners }\end{array}$ & $7(53.9)$ & $2(15.4)$ & $1(7.7)$ & $1(7.7)$ & $2(15.4)$ & $13(100)$ & $\begin{array}{c}3.85 \\
1.573\end{array}$ \\
\hline $\begin{array}{l}\text { Peer evaluation within the institution by } \\
\text { the colleague }\end{array}$ & - & $1(7.7)$ & $1(7.7)$ & $1(7.7)$ & $10(76.9)$ & $13(100)$ & $\begin{array}{l}1.46 \\
.967\end{array}$ \\
\hline
\end{tabular}

Bangladesh Journal of Medical Education 2015;6(1):2-7. 
Table 2.1 shows that $53.85 \%$ of the medical colleges never allowed and $7.69 \%$ medical colleges rarely allowed students representatives to remain present in the academic coordination meeting only $23.7 \%$ medical colleges allowed student representatives to remain present in the academic coordination meeting. Twenty three percent $(23 \%)$ medical colleges collected the evaluation from the students always and $15.38 \%$ medical colleges never collected phase wise evaluation done by students .Regarding filling up and evaluation of the personal review form $76.9 \%$ medical colleges never asked their faculty to fill up the form. Again $76.9 \%$ medical colleges did not do the practice of peer evaluation by the colleague. Majority of the medical colleges $(53.83 \%)$ collected the report of external examiners regularly.

Table 3. Distribution of the medical colleges by the opinion of authorities about the operational framework of the QAS

Table 2.2. Majority of the medical colleges $(61.54 \%$ \& $76.92 \%$ ) have faculty development and review committee and faculty development programme respectively . Nearly eighty five percent $(84.61 \%)$ medical colleges did not do any exchange review visit by the academic coordinators. Majority of the medical colleges $(53.85 \%)$ had external review visit by representative of Director, CME and

\begin{tabular}{|l|c|c|c|}
\hline $\begin{array}{l}\text { Issues / events related to } \\
\text { operational framework of } \\
\text { the QAS }\end{array}$ & \multicolumn{3}{|c|}{$\begin{array}{l}\text { Opinion of the authorities } \\
\text { about the operational } \\
\text { framework of the QAS }\end{array}$} \\
\hline & $\begin{array}{c}\text { Yesn } \\
\text { n (\%) }\end{array}$ & $\begin{array}{c}\text { No } \\
\text { n (\%) }\end{array}$ & $\begin{array}{c}\text { Total } \\
\text { n (\%) }\end{array}$ \\
\hline Academic Council & $13(100)$ & - & $13(100)$ \\
\hline $\begin{array}{l}\text { Academic co- ordination } \\
\text { committee }\end{array}$ & $13(100)$ & - & $13(100)$ \\
\hline Phase co-ordination group & $13(100)$ & - & $13(100)$ \\
\hline Subject coordinators & $13(100)$ & - & $13(100)$ \\
\hline $\begin{array}{l}\text { Student representatives in } \\
\text { the academic co-ordination } \\
\text { committee }\end{array}$ & $6(46.1)$ & $(53.8)$ & $13(100)$ \\
\hline $\begin{array}{l}\text { Student representatives in the } \\
\text { phase co-ordination group }\end{array}$ & $5(38.5)$ & $8(61.5)$ & $13(100)$ \\
\hline
\end{tabular}

Director, Medical Education, DGHS in the last year . Most of the medical colleges $(84.66 \%)$ have pair medical colleges . All most all the medical colleges $(92.31 \%)$ prepared and submitted the QAS report to NQAB in the last year.

Table 4. Distribution of the respondents' (students) level of satisfaction by the statements in relation to teaching learning factors

\begin{tabular}{|c|c|c|c|c|c|c|c|}
\hline \multirow[t]{2}{*}{ Teaching learning related factors } & \multicolumn{7}{|c|}{ Level of satisfaction in relation to teaching learning factors } \\
\hline & $\begin{array}{c}\text { VD } \\
\text { n } \\
(\%) \\
1\end{array}$ & $\begin{array}{c}\text { D } \\
\text { n } \\
(\%) \\
2\end{array}$ & $\begin{array}{c}\text { NSND } \\
\text { n } \\
(\%) \\
3\end{array}$ & $\begin{array}{c}\mathrm{S} \\
\mathrm{n} \\
(\%) \\
4\end{array}$ & $\begin{array}{c}\mathrm{VS} \\
\mathrm{n} \\
(\%) \\
5\end{array}$ & Total & $\begin{array}{l}\text { Mean } \\
( \pm \text { SD) }\end{array}$ \\
\hline $\begin{array}{l}\text { Knowledge of the teacher on the respective } \\
\text { subjects(preparation, clarity, explaining the topics } \\
\text { with examples etc) }\end{array}$ & $\begin{array}{l}11 \\
(1.4)\end{array}$ & $\begin{array}{l}48 \\
(6.3)\end{array}$ & $\begin{array}{l}115 \\
(51.1)\end{array}$ & $\begin{array}{c}461 \\
(60.7)\end{array}$ & $\begin{array}{l}125 \\
(16.4)\end{array}$ & 760 & $\begin{array}{r}3.84 \\
.822\end{array}$ \\
\hline Communication skill of the teachers & $\begin{array}{c}24 \\
(3.2) \\
\end{array}$ & $\begin{array}{c}107 \\
(14.1)\end{array}$ & $\begin{array}{c}177 \\
(23.4) \\
\end{array}$ & $\begin{array}{c}373 \\
(49.3) \\
\end{array}$ & $\begin{array}{c}76 \\
(10)\end{array}$ & 757 & $\begin{array}{l}3.49 \\
.962\end{array}$ \\
\hline Eye contact of the teacher throughout the class & $\begin{array}{l}23 \\
(3)\end{array}$ & $\begin{array}{c}66 \\
(8.7)\end{array}$ & $\begin{array}{c}158 \\
(20.8)\end{array}$ & $\begin{array}{l}409 \\
(54)\end{array}$ & $\begin{array}{c}102 \\
(13.5)\end{array}$ & 758 & $\begin{array}{l}3.66 \\
.922\end{array}$ \\
\hline Question and answer session & $\begin{array}{c}45 \\
(5.9)\end{array}$ & $\begin{array}{c}133 \\
(17.5)\end{array}$ & $\begin{array}{c}179 \\
(28.1)\end{array}$ & $\begin{array}{c}312 \\
(41.1)\end{array}$ & $\begin{array}{c}56 \\
(7.4)\end{array}$ & 759 & $\begin{array}{l}3.26 \\
1.025\end{array}$ \\
\hline Feedback provided by the teachers & $\begin{array}{c}27 \\
(3.6) \\
\end{array}$ & $\begin{array}{c}105 \\
(13.9) \\
\end{array}$ & $\begin{array}{c}195 \\
(25.9) \\
\end{array}$ & $\begin{array}{c}349 \\
(46.3) \\
\end{array}$ & $\begin{array}{c}77 \\
(10.2) \\
\end{array}$ & 753 & $\begin{array}{l}3.46 \\
.974 \\
\end{array}$ \\
\hline $\begin{array}{l}\text { Summary provided by the teachers at the end of the } \\
\text { presentation }\end{array}$ & $\begin{array}{l}34 \\
(4.5)\end{array}$ & $\begin{array}{l}153 \\
(20.2)\end{array}$ & $\begin{array}{c}158 \\
(20.9)\end{array}$ & $\begin{array}{l}348 \\
(46)\end{array}$ & $\begin{array}{c}63 \\
(8.3)\end{array}$ & 756 & $\begin{array}{c}3.33 \\
1.032\end{array}$ \\
\hline $\begin{array}{l}\text { Content coverage according to Curriculum/ } \\
\text { syllabus in this phase }\end{array}$ & $\begin{array}{l}66 \\
(8.7)\end{array}$ & $\begin{array}{c}119 \\
(15.7)\end{array}$ & $\begin{array}{c}142 \\
(18.8)\end{array}$ & $\begin{array}{c}346 \\
(45.8)\end{array}$ & $\begin{array}{c}83 \\
(11)\end{array}$ & 756 & $\begin{array}{c}3.35 \\
1.134\end{array}$ \\
\hline $\begin{array}{l}\text { The extent of importance of student's opinion in } \\
\text { teaching and learning }\end{array}$ & $\begin{array}{c}116 \\
(15.4)\end{array}$ & $\begin{array}{c}173 \\
(22.9)\end{array}$ & $\begin{array}{c}169 \\
(22.4)\end{array}$ & $\begin{array}{l}241 \\
(32)\end{array}$ & $\begin{array}{c}55 \\
(7.3)\end{array}$ & 754 & $\begin{array}{c}2.93 \\
1.205\end{array}$ \\
\hline Teacher student ratio & $\begin{array}{c}89 \\
(11.8)\end{array}$ & $\begin{array}{c}157 \\
(20.8)\end{array}$ & $\begin{array}{c}127 \\
(16.8)\end{array}$ & $\begin{array}{c}295 \\
(39.02) \\
\end{array}$ & $\begin{array}{c}88 \\
(11.6)\end{array}$ & 756 & $\begin{array}{c}3.18 \\
1.226\end{array}$ \\
\hline
\end{tabular}

$(\mathrm{NB}: \mathrm{VD}=$ Very dissatisfied, $\mathrm{D}=$ Dissatisfied, $\mathrm{NSND}=$ Neither satisfied nor dissatisfied

$\mathrm{S}=$ Satisfied, $\mathrm{VS}=$ Very satisfied )

Table 5 shows that most of the students responded positively about knowledge of the teachers $(77.1 \%)$, communication skill $(59.3 \%)$, eye contact $(67.5 \%)$, feedback $(56.5 \%)$, providing summary $(54.3 \%)$, content coverage $(56.8 \%)$ and teacher student ratio $(50.8 \%)$. No definite opinion could be revealed about extent of importance of students opinion in selecting topics/contents/objectives (mean 2.93) but a significant number of students $(38.3 \%)$ responded negatively.

Bangladesh Journal of Medical Education 2015;6(1):2-7. 
Table 4. Distribution of the respondents' (students) level of satisfaction by the statements in relation to teaching learning factors

\begin{tabular}{|c|c|c|c|c|c|c|c|}
\hline \multirow[t]{2}{*}{$\begin{array}{l}\text { Physical environment and library related } \\
\text { factors }\end{array}$} & \multicolumn{7}{|c|}{$\begin{array}{l}\text { Level of satisfaction in relations to physical environment of the } \\
\text { college and library facilities }\end{array}$} \\
\hline & $\begin{array}{c}\text { VD } \\
\text { n } \\
(\%) \\
1\end{array}$ & $\begin{array}{c}D \\
\text { n } \\
(\%) \\
2\end{array}$ & $\begin{array}{c}\text { NSND } \\
\text { n } \\
(\%) \\
3\end{array}$ & $\begin{array}{c}S \\
n \\
(\%) \\
4\end{array}$ & $\begin{array}{c}\text { VS } \\
\text { n } \\
(\%) \\
5\end{array}$ & Total & $\begin{array}{l}\text { Mean } \\
( \pm \text { SD })\end{array}$ \\
\hline $\begin{array}{l}\text { Physical environment of the classroom(sitting } \\
\text { arrangement, lighting, temperature, ventilation } \\
\text { etc) }\end{array}$ & $\begin{array}{c}122 \\
(16.1)\end{array}$ & $\begin{array}{c}147 \\
(19.4)\end{array}$ & $\begin{array}{c}123 \\
(16.2)\end{array}$ & $\begin{array}{l}303 \\
(40)\end{array}$ & $\begin{array}{c}62 \\
(8.2)\end{array}$ & 757 & $\begin{array}{l}3.05 \\
1.252\end{array}$ \\
\hline $\begin{array}{l}\text { Availability of required number of books in the } \\
\text { library }\end{array}$ & $\begin{array}{c}111 \\
(14.7)\end{array}$ & $\begin{array}{c}132 \\
(17.5)\end{array}$ & $\begin{array}{c}111 \\
(14.7)\end{array}$ & $\begin{array}{c}294 \\
(38.9)\end{array}$ & $\begin{array}{c}108 \\
(14.3)\end{array}$ & 756 & $\begin{array}{l}3.21 \\
1.297\end{array}$ \\
\hline Extent of opportunities for internet use & $\begin{array}{c}345 \\
(45.5)\end{array}$ & $\begin{array}{l}197 \\
(26)\end{array}$ & $\begin{array}{c}105 \\
(13.9)\end{array}$ & $\begin{array}{c}86 \\
(11.3)\end{array}$ & $\begin{array}{c}25 \\
(3.3)\end{array}$ & 758 & $\begin{array}{l}2.01 \\
1.160\end{array}$ \\
\hline Extent of opportunities for photocopy & $\begin{array}{c}337 \\
(44.7)\end{array}$ & $\begin{array}{c}217 \\
(28.8)\end{array}$ & $\begin{array}{c}88 \\
(11.7)\end{array}$ & $\begin{array}{c}91 \\
(12.1)\end{array}$ & $\begin{array}{c}21 \\
(2.8)\end{array}$ & 754 & $\begin{array}{l}1.99 \\
1.140\end{array}$ \\
\hline $\begin{array}{l}\text { Opportunities for extracurricular activities in the } \\
\text { college (like sports, cultural programmes magazine } \\
\text { etc) }\end{array}$ & $\begin{array}{c}285 \\
(37.7)\end{array}$ & $\begin{array}{l}181 \\
(24)\end{array}$ & $\begin{array}{c}124 \\
(16.4)\end{array}$ & $\begin{array}{c}131 \\
(17.4)\end{array}$ & $\begin{array}{c}34 \\
(4.5)\end{array}$ & 755 & $\begin{array}{l}2.27 \\
1.253\end{array}$ \\
\hline $\begin{array}{l}\text { Arrangements for accomodation in the hostel (if } \\
\text { applicable) }\end{array}$ & $\begin{array}{c}313 \\
(43.1)\end{array}$ & $\begin{array}{c}171 \\
(23.5)\end{array}$ & $\begin{array}{c}106 \\
(14.6)\end{array}$ & $\begin{array}{c}95 \\
(13.1)\end{array}$ & $\begin{array}{c}42 \\
(5.8)\end{array}$ & 727 & $\begin{array}{l}2.15 \\
1.264\end{array}$ \\
\hline $\begin{array}{l}\text { Arrangements for meals in the hostel (if } \\
\text { applicable) }\end{array}$ & $\begin{array}{c}339 \\
(46.8)\end{array}$ & $\begin{array}{c}164 \\
(22.6)\end{array}$ & $\begin{array}{c}101 \\
(13.9)\end{array}$ & $\begin{array}{c}95 \\
(13.1)\end{array}$ & $\begin{array}{c}26 \\
(3.6)\end{array}$ & 725 & $\begin{array}{l}2.04 \\
1.206\end{array}$ \\
\hline
\end{tabular}

(NB : VD = Very dissatisfied, $\mathrm{D}=$ Dissatisfied, NSND $=$ Neither satisfied nor dissatisfied

$\mathrm{S}=$ Satisfied, $\mathrm{VS}=$ Very satisfied )

Table 10. No definite opinion could be revealed about the physical environment of the classroom (mean 3.05), though significant number of students $(48.2 \%)$ responded positively on the above factors . Most of the respondents gave negative opinion regarding opportunities for internet use $(71.5 \%)$,opportunities for photocopy $(73.5 \%)$, opportunities for extracurricular activities in the college (61.7\%), arrangements of accommodation (66.6\%) and arrangements for meal in the hostel (69.4\%). Slightly positive responses were obtained about availability of books in the library (53.2\%).

\section{Discussion}

Globalization of medicine is increasing, as manifested by the growing number of migrating doctors and cross boarder education providers . In addition, new medical colleges of dubious quality are proliferating. This situation accentuates the need to define standard and introduce effective and transparent accreditation system. With this background and reflecting the important interface between medical education and health care delivery a strategic partnership was formed between WHO and WFME in 2004 to improve medical education (Talukder et al 2010). The WHO/ WFME guidelines recommended establishing accreditation that is effective, independent, transparent ,and based on criteria specific to medical education. The standard are now being used in all regions as a basis for improving medical education through out its continuum and as a template for national and regional accreditation standards (Karle 2006)

In quality improvement of medical education, indispensable components are institutional self-evaluation, external review, and consultation. Both the structure and the function of WFME are conducive to the Federation participating in setting up consultation teams in the entire world regions and in "recognizing the creditors", thereby establishing a system of international transparency of the quality of medical education programmes (WFME Global Standards for Quality Improvement 2012 p.7).

Standard for medical education have been used for many years in national system of evaluation and accreditation of medical education in many countries. The methods used for these differ from country to country. The WFME presented global standard in this trilogy covering all three phases of medical education; basic medical education, postgraduate medical education and continuing professional development (International standard in medical education; The Executive Council, WFME, 1998).

In Bangladesh, QA activities have been practicing since 1998 in different medical colleges for the improvement of medical education. Initially there was Quality Assessment and Audit Review (QAAR) at three medical colleges (Dhaka Medical College, Chittagong Medical College and Rangpur Medical College ) under the project "Further 
Improvement of Medical Colleges" (FIMC) National Quality Assurance Body (NQAB) was formed in January 1998 to oversee quality assurance in medical education to ensure that standards are maintained in all medical colleges . They review the MBBS course every after 3 to 5 years. But there was some lacking in formal auditing and of quality assurance activities . In March 2008 decisions were taken to run the QAS in all undergraduate and post graduate medical and dental colleges (Talukder et al 2010). National guidelines and tools for QAS for medical colleges have been reviewed in 2012 by CME and DGHS supported by WHO.

This descriptive type of cross sectional study was carried out in 13 medical colleges of Bangladesh to assess the present status of practice of QAS. Seven hundred sixty students and 13 principals/ academic coordinators were included in the study. Opinion of the authorities about the institutional and operational framework of the QAS showed that $80.8 \%$ of the medical colleges have complete institutional framework and $68.1 \%$ medical colleges have complete operational framework of the QAS . Majority of the medical colleges $(53 \%)$ do not have student representatives in academic co-ordination committee and $61.5 \%$ medical colleges do not have student representatives in phase co-ordination group (Table 1). Only 23\% medical colleges collected the phase wise evaluation of the course by the students always (Table 2). This reflects that our teaching learning system in medical colleges is very much teacher centered (Nahar et al 2010). If we discuss the teaching learning system in light of SPICES model, it is very much to the right on most of the dimension (Amin et al).

In the present study it has been found that majority of the medical colleges $(61.54 \%$ \& $76.92 \%)$ have faculty development and review committee and faculty development programme respectively (Table 3 ). Study revealed that $76.9 \%$ medical colleges never asked their faculty to fill up the personal review form or hold annual review meeting for faculty development. Same percentage of medical colleges never did peer evaluation (Table 2). Peer evaluation is an effective tool in developing an awareness of one's own working method and encouraging objective self examination. It promotes critical thinking and creativity. It enhances the development of strategies, attitude and skill essential for life long learning. Peer evaluation is a process of faculty development (Talukder 2013).

Study revealed that only $15.4 \%$ medical colleges had exchange review visit by the academic coordinator of the pair medical colleges (Table 3). Majority of the medical colleges (53.85) had external review visit by representative of Director, CME and Director, Medical Education, DGHS in the last year. Regarding preparation and submission of the annual report on QAS to the NQAB all most all the selected medical colleges (92.31\%) prepared and submitted the report on QAS to NQAB in the last year but the report itself and on ground practice of every item of QAS was not complete. (Table 3 ).

Study showed that the responses of the students in relation to teaching learning were positive $(56.7 \%)$. Different factors/ issues of teaching learning like, knowledge of the teachers on the specific subjects $(77.1 \%)$, communication skill of the teachers (59.3\%), eye contact (63.5\%), feedback $(56.5 \%)$, providing summary $(54.3 \%)$ were favourable (Table 4) .A significant number of students (38.6\%) gave negative answer to the statement about importance of students opinion in selecting course objectives / topics.

Paradigms about the instructional methods, learning strategies, curricular structure, aims and goals have been changed. Medical education has moved from traditional lectures towards experienced based method; from teacher centred to learner centred strategies; from rigid curricula towards a flexible one with core and electives and from a focus of knowledge to performance and outcomes (Montemayor 2004 p. 400).

'Educational environment' defined as everything that happens within the classroom, department, faculty or university is crucial in determining the success of undergraduate medical education (Genn 2001). Students perceptions of educational environment significantly impact their academic progress and sense of well being. In the present study no definite opinion could be revealed (mean 3.05) regarding physical environment of the classroom, though significant number of the students (48.2\%) responded positively. Little positive responses were obtained about availability of books in the library (53.2\%). Most of the respondents expressed their dissatisfaction regarding opportunities for internet use $(71.5 \%)$,opportunities for photocopy (73.5\%), opportunities for extracurricular activities in the college (61.7\%), arrangements of accommodation (66.6\%) and arrangements of meal in the hostel (69.4\%) (Table 5).

The science and art of treating patients and preventing disease is complex and multi-dimensional. Offering students rigorous, high-quality education and training in the science and skills involved in the provision of care is the goal of undergraduate medical education programmes. It requires acquisition of broad range of competencies in knowledge, communication skill, technical skill, teamwork, professionalism, leadership and others . The outcome should be comparable with outside / external world. Good quality in medical education is a vital prerequisite to ensure quality of future physicians, researchers and teachers. The students of today are the colleagues of tomorrow. Quality education should be the goal of each teacher and every academic institution (Kulike 2004 ).

\section{Conclusion}

In order to improve the medical education in a systematic and effective way quality assurance is the first step on the way to quality improvement. Quality improvement is a continuous and dynamic process to review, critique and change in order to make medical education better. Quality is not a goal but a process. We want quality in educational

Bangladesh Journal of Medical Education 2015;6(1):2-7. 
outcome, quality in educational programme, quality in students assessment and quality of teachers- through evaluation, follow up and obtaining international standard and guidelines ( Kulike 2004). Quality medical education is the responsibility of all the teachers, students, administrators and management of the institution. Our ultimate goal should be to improve the quality of healthcare and that will happen only if we take care of the quality of medical education.

\section{References}

1. Amin Z, Merrylees N, Hanif A \& Talukder MHK 2008, Medical education in Bangladesh, Medical Teacher, vol. 30, no.3, pp. 243-244

2. Centre for Medical Education( CME) \& Directorate General of Health Services (DGHS) 2012, National Guidelines and Tools for Quality Assurance Scheme (QAS) for Medical Colleges in Bangladesh, pp. 3-6

3. Gale R \& Grant J 2011, Quality assurance systems for medical education, Chap, 13

4. Genn JM 2001, Amee Medical Education Guide no. 23 (part 2), Curriculum, environment, climate, quality and change in medical education a unifying perspective, Medical Teacher vol. 23, no.5

5. Griffin RW, Management, $7^{\text {th }} E D, 2003$, Texas A \& M University, Houghton Mifflin Company, Boston New York,

6. International standard in medical education ; assessment and accreditation, A WFME Position Paper. The Executive Council, WFME, 1998.

7. Joshi MA 2012, Quality assurance in medical education, Indian Journal of Pharmacology, vol. 44 , (3) pp. $285-287$

8. Karle H 2006, Global Standards and Accreditation in Medical Education: A View from the WFME" Supplement on the occasion of the ECFMG $50^{\text {th }}$ Anniversary Invitational
9. Kulike K 2004, Quality assurance and quality improvement ; The students perspective, German Medical Students Association, Website www.kulike_ vortrage [1].pdf

10. Montemayor LLE-2004, How we assess students using an holistic standardized assessment system: Medical Teacher, vol. 26, no. 5, p. 400

11. Nahar N, Talukder MHK, Khan MTH , Mohammad S \& Nargis T 2010, Students perception of educational environment of meical colleges in Bangladesh, BSMMU J, vol.3(2), p. 97

12. Sallis E 2002, Total Quality Management in Education, London: Kogan Page Ltd.

13. Talukder MHK 2010, Quality Control in Medical Education Global and Bangladesh Perspective Bangladesh Journal of Medical Biochemistry, vol.3, no.1

14. Talukder MHK 2013, Lecture note on Self Assessment , CME, Mohakhali, Dhaka

15. Talukder MHK, Nazneen R, Hossain MZ, Nargis T, Alam KK, Chowdhury IJ \& Parveen I 2010, QAS in Medcal and Dental Colleges in Bangladesh- Teacher's Knowledge; Bangladesh Journal of Medical Biochemistry, vol. 3, no.1

16. WFME Global Standards for Quality Improvement, Basic Medical Education, WFME Office Copenhagen, 2012, WFME Website www.wfme.org.

17. WHO, Changing Medical Education: An Agenda for Action. Unpublished Document WHO/EDUC/91.200, Geneva, 1991.

18. WHO/WFME Guidelines for Accreditation of Basic Medical Education. Geneva/Copenhagen 2005, WFME Website: www.wfme.org.

Bangladesh Journal of Medical Education 2015;6(1):2-7. 